\section{ARE SOCIAL SERVICES EQUALLY ACCESSIBLE TO ALL CITIZENS IN SPAIN? YOUTH AND THE SPANISH WELFARE STATE}

\author{
Antonio López Peláez \\ Universidad Nacional de Educación a Distancia (UNED) \\ Western Michigan University (WMU) \\ alopez@der.uned.es /antonio.lopez-pelaez@wmich.edu \\ Sagrario Segado Sánchez-Cabezudo \\ Universidad Nacional de Educación a Distancia (UNED) \\ ssegado@der.uned.es
}

Citation/Cómo citar este artículo: López Peláez, A. and Segado Sánchez-Cabezudo, S. (2015). "Are Social Services equally accessible to all citizens in Spain? Youth and the Spanish Welfare State". Arbor, 191 (771): a205. doi: http:// dx.doi.org/10.3989/arbor.2015.771n1007

Received: January 16, 2014. Accepted: July 25, 2014.

ABSTRACT: Young people are a central target of social policies. In the Spanish case, we will take into consideration the European context, as our regulations and our programmes are integrated into the main European Union policy guidelines for young people. In the European Union, the participation of young people in designing and managing such policies through social services is considered a priority. However, social spending on youth in Europe is limited, and even more so in the countries of southern Europe. In this paper we analyse the available data on social services activities targeted on Spanish youth. Our findings show the decreasing importance youth play in social policies in a context where the family has become the main provider of resources.

KEYWORDS: Social services; youth; social work; Spanish welfare state.

\section{¿SON LOS SERVICIOS SOCIALES IGUALMENTE ACCESIBLES PARA TODOS LOS CIUDADANOS? LA JUVENTUD Y EL ESTADO DE BIENESTAR ESPAÑOL}

Copyright: $@ 2015$ CSIC. This is an open-access article distributed under the terms of the Creative Commons Attribution-Non Commercial (by-nc) Spain 3.0 License.
RESUMEN: Los jóvenes son un objetivo central de las políticas sociales. En el caso español, hay que tener muy en cuenta el contexto europeo, ya que nuestras normas y programas nacionales incorporan las principales orientaciones que ofrecen las políticas de la Unión Europea para los jóvenes. A nivel europeo, la participación de los jóvenes en el diseño y la gestión de este tipo de políticas a través de los servicios sociales se considera una prioridad. Sin embargo, el gasto social en los jóvenes europeos es limitado, y más aún en los países del sur de Europa. En este trabajo se analizan los datos disponibles sobre las actividades de los servicios sociales dirigidos a los jóvenes españoles. Nuestros resultados muestran la disminución de la importancia de jóvenes en las políticas sociales, en un contexto donde la familia se ha convertido en el principal proveedor de recursos.

PALABRAS CLAVE: Servicios sociales; juventud; trabajo social; Estado de Bienestar español. 


\section{INTRODUCTION}

In this paper we present the results of our research on a key social policy: the interaction between youth and social services. We analyze the reality of youth social services in Spain. Taking as a reference the objectives of youth policies in the European Union, which are characterized by autonomy, independence and participation, we inquire as to what extent social policies aimed at young people have been overlooked in the Spanish welfare system.

In a context of deep economic crisis, in which the viability of the welfare state is being challenged from different theoretical positions (Featherstone, Broadhurst and Holt 2012; Kim, Muntaner, Shahidi, Vives, Vanroel and Benach 2012), European welfare states must address a key issue: youth social policies (Furlong, 2009). In the Spanish case, the situation is particularly dramatic because the Spanish youth has a level of unemployment that is twice the European average, they become independent later than their counterparts in central and northern Europe, and depends on family ties to survive. However, it cannot be analyzed the Spanish situation if we don't taken into account a double factor: On one hand, the European context, and inside, the peculiarities of the Spanish welfare system, in which clearly young people are a sparsely attended group. On the other hand, and drawing on the theoretical models that come from the successful experience of the countries of northern Europe, we can address the specific situation of Spanish youth regarding social services and social work.

In this sphere, as in others, the model of northern European countries has become a point of reference for discussion and debate in southern European countries. As noted by Castells and Himanen (2002), the model of technological development and state policies aimed at strengthening the welfare state characteristic of Finland has become a reference for the rest of the European Union and especially for Spain. In the field of youth policy, the models of Sweden, Finland, Norway and Denmark can be defined as universal as they aim to protect and revitalize all dimensions of young people's lives. The administrations of these countries provide all types of financial aid to encourage youth to follow their individual life paths and achieve independence. A key point in this model is the feedback between public policies and civil society as there does not exist a ministry of social intervention aimed at young people. Youth play a key role in designing their own social policies and because of this have a high degree of social participation through various social organizations. Young people are seen by their own society as a resource rather than a problem, and the objectives of youth policies, in line with that vision, are autonomy, independence, and social and political participation (Wallace and Bendit, 2009).

Perhaps where this issue is best observed is in the pattern of emancipation. The expectations and values of European youth are very similar across countries. The age considered ideal to leave the family home ranges from 20 to 21 years old (Moreno Mínguez, López Peláez and Segado Sánchez-Cabezudo, 2012). However, depending on the institutional context and family structure, as well as social policies and social services, we see substantial differences according to country of residence. For example, 24\% of Finnish youth aged 15 to 29 live with their parents compared with $55 \%$ of Spaniards of the same age (Eurostat, 2009). Young people in northern Europe leave the family home at an earlier age than Spanish youth (Table 1).

Table 1. Emancipation age

\begin{tabular}{lcc}
\hline & $\begin{array}{c}\text { Expected age to leave family home in 2006 } \\
\text { (European Social Survey 2009) }\end{array}$ & $\begin{array}{c}\text { Age to leave family home in 2007 } \\
\text { (Eurostat 2010) }\end{array}$ \\
\hline Denmark & 19.0 & *(Data not available) \\
\hline Finland & 20.0 & 22.5 \\
\hline Sweden & 19.9 & *(Data not available) \\
\hline United Kingdom & 20.4 & 24.1 \\
\hline Spain & 21.7 & 28.8 \\
\hline
\end{tabular}

Source: Moreno, A., López Peláez, A. and Segado Sánchez-Cabezudo, S. (2012:42). The Transition to Adulthood in Spain. Economic Crisis and Late Emancipation. Barcelona: "La Caixa” Welfare Projects. 
The residential patterns of youth in northern European countries are not always associated with living with a partner or forming a family, while the majority of young people in Spain delay leaving home until they live with a partner and have children. In northern European countries, for example in Sweden, 33.1\% of men and $23.4 \%$ of young women live alone after becoming emancipated compared with $3.5 \%$ of men and $1.6 \%$ of women in Spain. Cohabitation is also widespread among Swedish youth aged thirty years old without children (81.5\%), but not among the Spanish (27.4\%) (European Labour Survey, 2009).

The available studies focus primarily on specific countries and cities (Bradley and van Hoof, 2005; Leccardi and Ruspini, 2006; Comas, 2011). Wallace and Bendit (2009) propose a descriptive typology of social policy models for young people, in which Spain is included within what they call a centralized model, together with Greece, Portugal and Italy. Within the European Union, Spain is the country where young people remain in the parental home longest and the youth unemployment rate is the highest (Moreno Mínguez, López Peláez and Segado Sánchez-Cabezudo, 2012). From the perspective of social work, it is important to analyze youth policies, and specially the relationship between the welfare state, social services and the living conditions of young people (Arias Astray and Sánchez Moreno 2012). In this sense, we have conducted over the past three years our research on social services and youth in Spain. The available data show a progressive distancing between youth and the social services. We demonstrate this trend by 1 ) analyzing the most relevant data on the social situation of youth and the main issues affecting them, 2) using available data on social services and youth; and finally, 3) examining the growing alienation between youth and social services.

The analysis of youth in Spain brings to light two key aspects. On the one hand, we find that young people are alienated from institutions (Aliena, Fombuena and García, 2012), organize themselves through social networks, encounter difficulties in making the transition from the family household to their own homes and from school to paid employment, weave their interrelational networks across the Internet and are involved in social movements such as the 15-M protests (which were subsequently reproduced in many countries). On the other hand, the Spanish welfare state delegates support for young people in families, while focusing on other age groups (Moreno Mínguez, López Peláez and Segado Sánchez-Cabezudo, 2012).
Social services are the last barrier against social exclusion processes in this age group. Often, many serious problems of social disintegration and exclusion begin during youth (López Peláez, 2012; Tezanos, 2007). The failure of youth transitions (emancipation from the family home and incorporation into the labor market) are the starting point of a downward spiral which ultimately leads to a situation of severe social exclusion. It is therefore necessary to design social services programs targeted specifically at young people to aid them in their life and career paths and promote their social inclusion.

\section{A FORGOTTEN GROUP? CHARACTERISTICS OF YOUNG PEOPLE IN SPAIN}

Spanish youth currently face a very difficult situation (Moreno Mínguez, 2013). The high unemployment rates among Spanish youth must be analyzed taking into account the high percentage of temporary contracts among young workers, the higher risk of occupational accidents among this group, and low wages. It is a vicious circle in which the sequence of unemployment, temporary employment, low wages, and unemployment once again result in the disqualification of young workers, whose health is often threatened. On the other hand, Spanish youth remain in the family home until a late age, and largely distrust basic state institutions.

As we will show below, these feelings of distrust are justified in the fact that the welfare state does hold young people to be a priority. To do so, first we briefly present some characteristics of Spanish youth and subsequently analyze the job market and the process of youth emancipation.

\subsection{What are Spanish youth like? Education and em- ployment: The road to full integration}

Given the scope of our research, youth and Social Services, it is relevant to analyze the interactive social context in which Spanish youth operate where employment, or the lack thereof, is becoming the preferred channel of inclusion or exclusion for this group. Moreover, we have identified four key areas to investigate the situation of young people in Spain (López Peláez and Segado Sánchez-Cabezudo, 2009a): educational level, the economy, the family, and institutional support. Throughout this paper, each of these factors will be given more or less prominence, yet all will be present in our efforts to draw an objective picture of the situation of young people in the Spanish welfare state and the role social services play in minimizing the risks facing young people and improving their living conditions. 
As regards educational attainment, we find that Spanish youth today have the highest level of education in the history of Spain (INE, 2013): Schooling is compulsory up to the age of 16 . In Spain, between $37 \%$ and $41 \%$ of youngsters up to the age of 34 continue to higher education. Another $24 \%$ undergo vocational training ${ }^{1}$, while $26 \%$ of young people will stop studying once they finish compulsory education.

However, this high educational level often does not lead to employment chiefly due to problems derived from a labor market characterized by temporary contracts ${ }^{2}$, intermittent unemployment, occupational risks (López Peláez and Segado Sánchez-Cabezudo, 2009b), the disappearance of linear careers (careers in which the worker, after getting the first job remains in stable professional career, and he/she may get an improvement in profits and positions -not alwaysuntil the retirement age), and the mismatch between qualifications and the jobs performed (García Montalvo and Peiró 2008; Refrigeri and Aleandri, 2013).

Regarding access by youth to the labor market, a retrospective glance at the last 15 years reveals that unemployment rates among youth in Spain are alarming (Figure 1). However, there is one fundamental difference: the high unemployment rate among young people aged 16 to 19 is, in most cases, due to the fact that those in this age group are still studying, while the unemployment rate in the 20-24 year age group is particularly high at around $43 \%$.

To a certain extent, these unemployment rates are what retain youth in the education system. Given the difficulties in finding work, young people choose to continue their training and become increasingly qualified to promote their inclusion, while those aged 30 to 34 (i.e., when "the young are no longer young") are able to access somewhat steady employment and gradually build a professional career that becomes more stable over time (Freire 2009; Gorry, 2013).

\section{FAMILY AND INSTITUTIONAL SUPPORT FOR YOUNG PEOPLE VIA THE SOCIAL SERVICES}

As we have seen, the challenges facing young people in Spain today are complex and diverse. Their vulnerability increases in direct proportion to the rising unemployment rates and increasing difficulties involved in finding a stable and well-paid job (Gorry, 2013). In contrast to European Union publications on youth (Council of the European Union, 2009) which call for improving the living conditions of young people and fostering their participation in policy making, a detailed analysis of the situation in Spain reveals that social services targeted specifically at youth are gradually being eliminated.

Figure 1. Evolution of youth unemployment in Spain

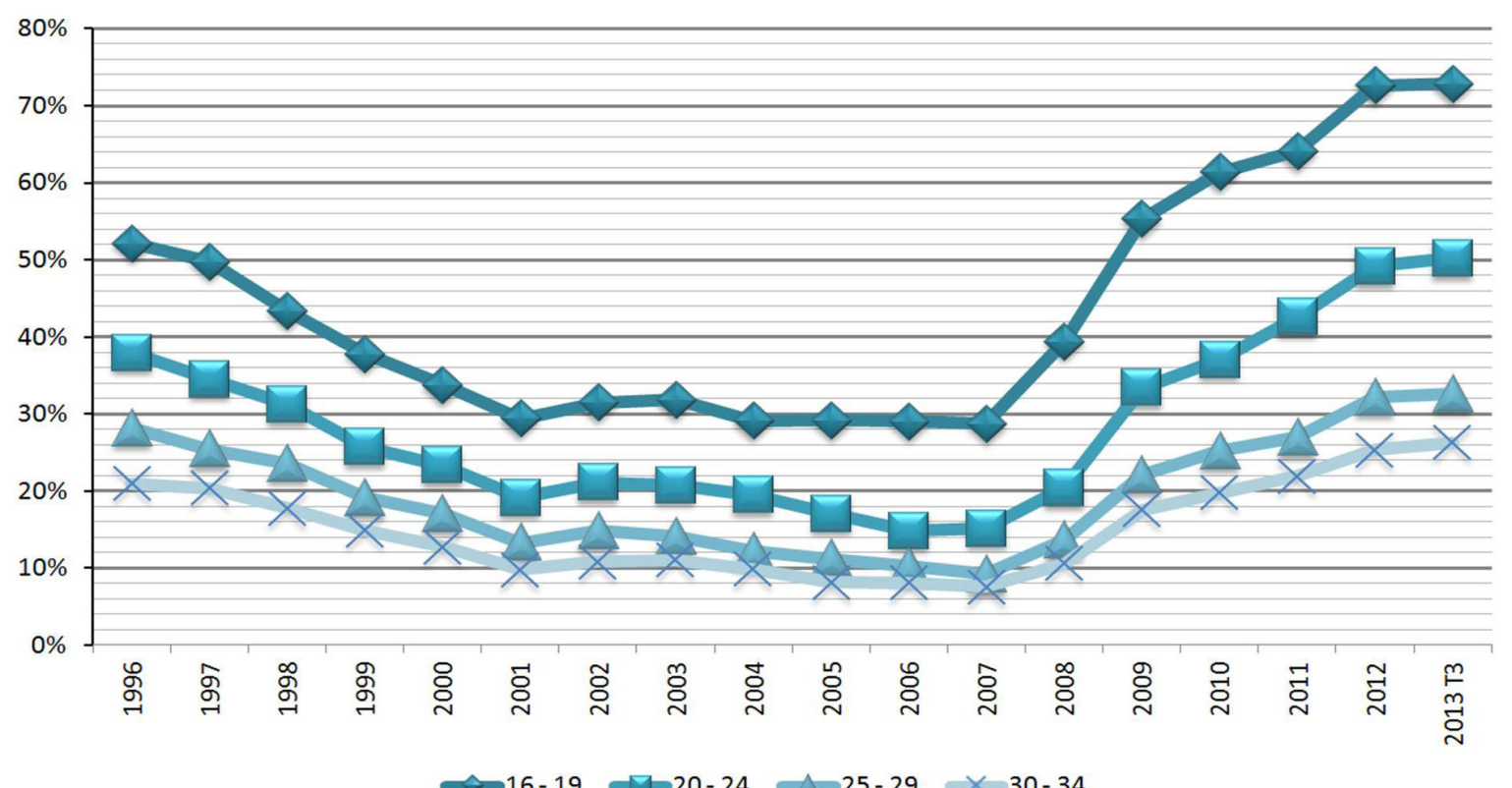

Source: Authors based on EPA data (1996-2013). 


\subsection{The family: The main source of support for Spa-} nish youth

The Spanish social services model differs from other countries of the European Union in several aspects. In Spain, social intervention programs and the provision of resources have been largely designed to protect a specific group: citizens over the age of 65 , thus relegating youth and youth policies to a secondary position. This assistentialist vision of the social services and the fact that such services focus primarily on the elderly are mutually reinforcing, giving rise to a model that does not take young people into account and in which fewer resources are devoted to youth than the elderly.

The Spanish welfare model is grounded in family solidarity. The family is primarily responsible for the socialization of the young (Del Fresno García, 2011) and is in charge of responding to their demands for resources and support through dynamic and inter-generational solidarity. Within this framework of institutional subsidiarity regarding protection between members of a household, government agencies are responsible for providing compulsory education, universal health care and basic security in addition to influencing the labor market structure. Problems such as increased longevity and lack of personal autonomy have been addressed at the institutional level through the socalled Dependency Act (Act 39/2006 of 14 December for the Promotion of Personal Autonomy and Care for Dependent People-LAAD). However, unlike the budgetary resources set aside to protect the personal autonomy of the elderly, spending to combat high youth unemployment rates, the late emancipation of Spanish youth with regard to the family of origin, and falling birth rates is very limited.

In comparing Spain to other European Union countries, two issues come to light. On the one hand, there is no evidence that increased spending on the elderly crowds out spending on the young (Börsch-Supan, 2007). On the other hand, the average social expenditure on young people is far lower in Spain, Italy or Portugal than in Denmark or Sweden (Chiuri and del Boca, 2008; Greve, 2011). In 2009, for example, youth social policies (active labor market policies, housing assistance and other social policies) accounted for $3.8 \%$ of total social spending in Germany, 6.5\% in Denmark, 4.4\% in Sweden, 3.9\% in France, 3.4\% in Finland, and only $2.9 \%$ in Spain, $1.5 \%$ in Portugal, and $1.2 \%$ in Italy (Moreno Minguez, López Peláez and Segado SánchezCabezudo, 2012). These disparities may be explained by the lower visibility of young people in more familyoriented countries. As young people are not considered an evident and objective problem, fewer resourc- es are devoted to them, regardless of the resources devoted to the elderly. At the same time, the greater social and political visibility of the elderly could explain increased social spending on this group. Whatever the case may be, insofar as parents are the sole or main social protectors of young people, social services lack visibility among youth.

\subsection{Youth and social services: A snapshot of the si- tuation in Spain}

In this context, how important are youth policies within the social services? How do the social services deal with the problems and challenges facing youth? Two approaches can be taken to address these issues. First, the analysis of available data on interventions targeted specifically at youth, and secondly, the analysis of participatory mechanisms that take account of the views of young people as actors in their own process of change.

\subsubsection{Applied resources and youth in social services of Spain}

At all levels of the state administration, from central to regional and local authorities, youth policies are highly relevant from a theoretical standpoint (Checkoway and Aldana, 2013). But what occurs with regard to intervention programs? Do young people actually make use of social services?

The profile of general social services recipients can be analyzed using data from the SIUSS ${ }^{3}$ for 2009 (latest data available). When professionals (normally social workers) come into contact with social services users, they evaluate their demands and needs. During this assessment process, users are assigned to a category in the SIUSS. The categories that are used to define the profile or characteristics of social services recipients are: 1) sex, 2) age, 3) educational level, 4) nationality, 5) target sector, 6) disability, 7) economic activity and 8) living conditions.

Focusing specifically on the categories "age" and "target sector", we can analyze both the percentage of young social service users (Figure 2 ) as well as the proportion of young users relative to the general population (Figure 3). In both cases, we find that a low percentage of young people access social services not only in terms of total numbers $(11.01 \%$ from 18 to 30 years of age) but in terms of how they are classified. Users who are classified as youth (for which specific activities or programs must be developed) account for only $1.18 \%$ of total users, while users belonging to other sectors are much more numerous, namely the elderly (37.63\%), families (24.08\%), and the disabled (12.97\%). 
Figure 2. Number of social services recipients by age (2009)

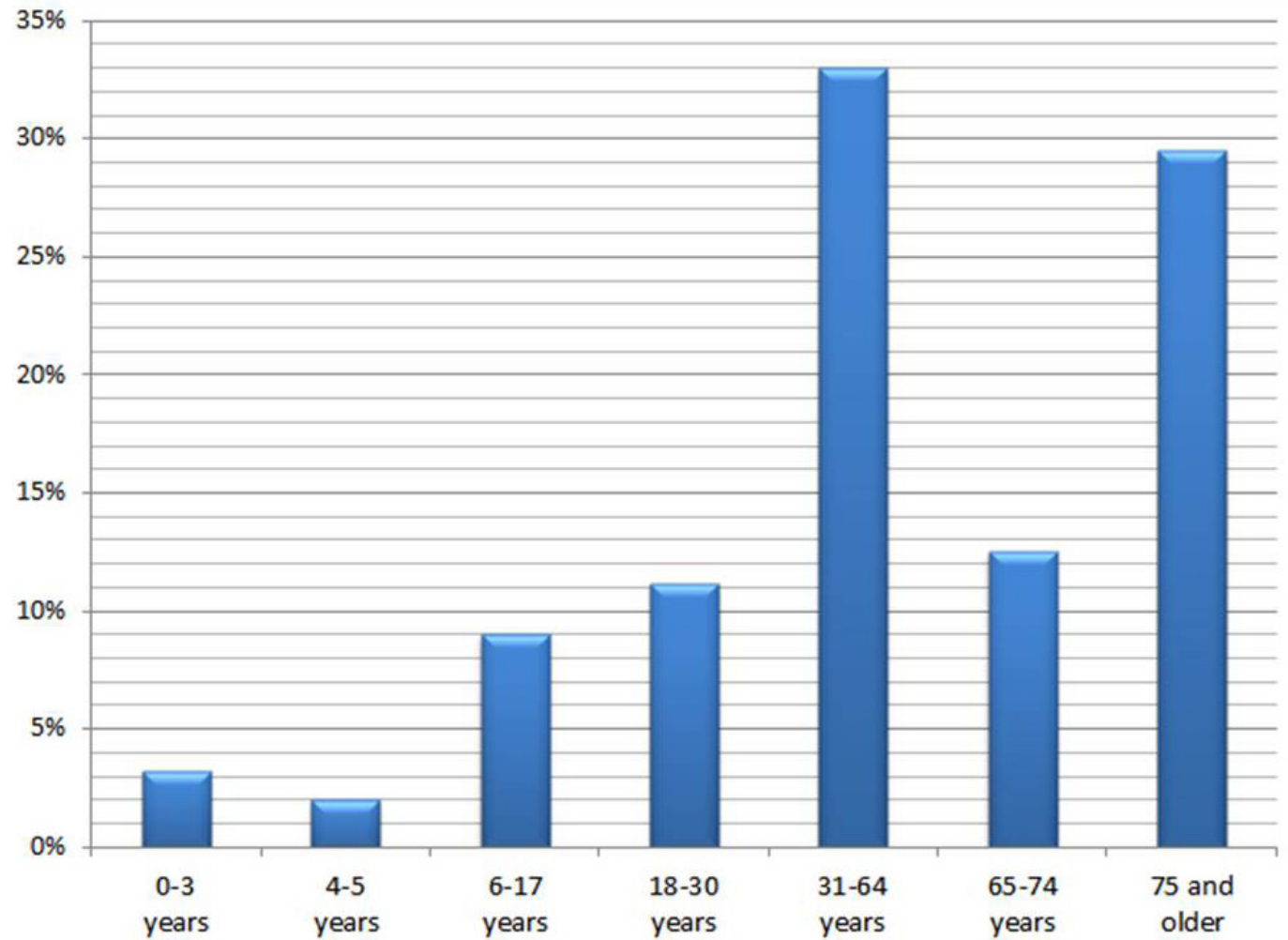

Source: Spanish Ministry of Health, Social Policy and Equality (SIUSS, 2009-2010).

Figure 3. Number of social services recipients by target sector (2009)

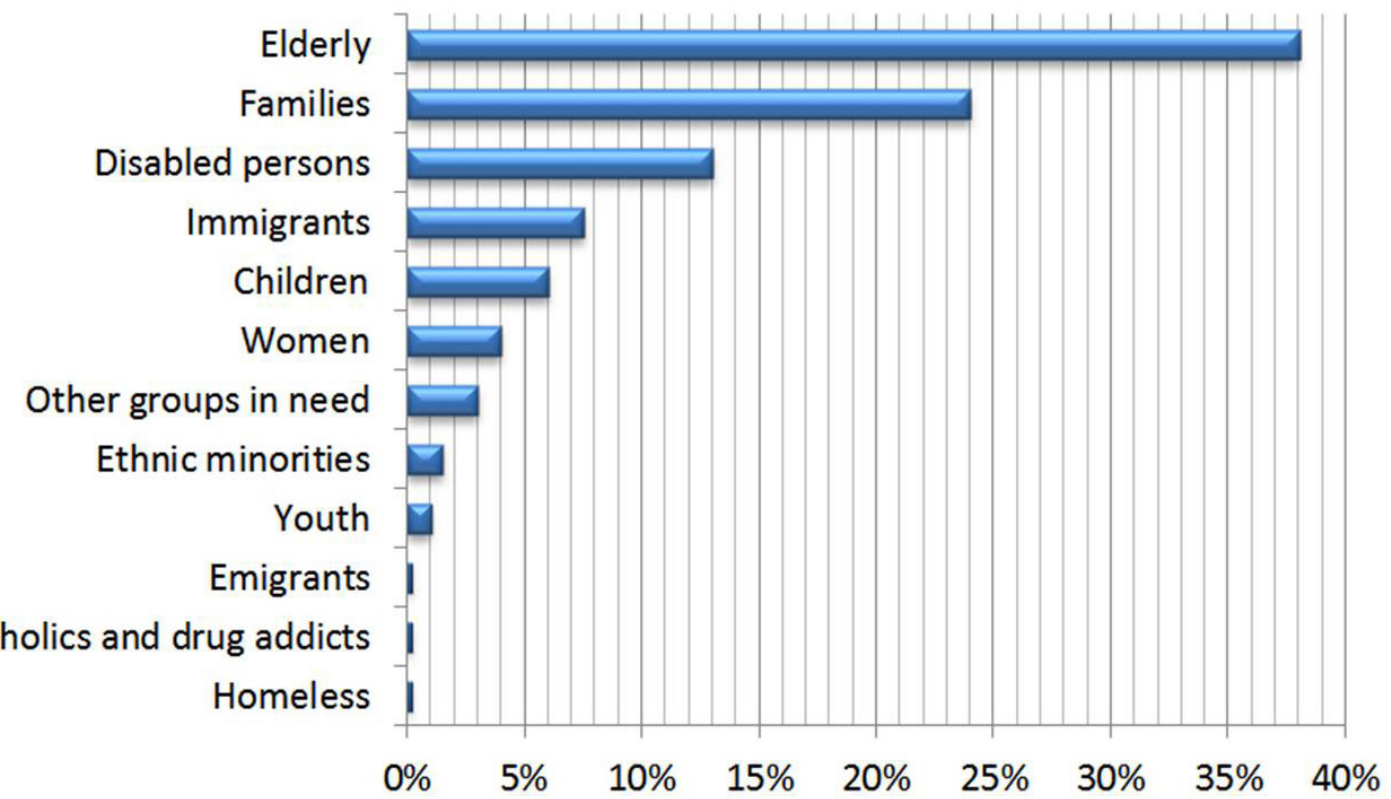

Source: Spanish Ministry of Health, Social Policy and Equality (SIUSS, 2009-2010). 
Similarly, according to SIUSS data, the types of interventions undertaken in the last three years indicate a context of high vulnerability for this group. Interventions among youth have been characterized by an increase in actions related to labor issues (from $7.04 \%$ in 2007 to $10.2 \%$ in 2009 ), the social wage ${ }^{4}$ (from $2.85 \%$ in 2007 to $5.06 \%$ in 2009), emergency assistance (from $2.31 \%$ in 2007 to $4.05 \%$ in 2009), the coverage of subsistence (to supplement other benefits such as aid for food, clothing, etc.) (from $3.58 \%$ in 2008 to $5.28 \%$ in 2009), and unemployment benefits (from $2.58 \%$ to $3.32 \%$ ).

Despite the economic crisis, which began with the subprime mortgage crisis in the United States in September 2007, interventions among youth have not increased in recent years. According to SIUSS data, the percentage of young recipients of social services accounted for only $1.29 \%$ of all recipients (a very low figure) in 2007 , while that percentage fell to $1.16 \%$ in 2008 and remained almost the same in 2009 at $1.18 \%$.

\subsubsection{Participation by youth in the social services}

Involving social services users of all ages is key to establishing a model of interaction based on citizenship that goes beyond the definition of users as passive recipients of charity and care which are determined without their participation (Domenech and Giménez 2012; Teney and Hanquinet, 2012). From a perspective based on citizenship and focusing on the central role of individuals as active subjects capable of managing their own lives, participation by young users permits determining the benefits and services they need and the most appropriate way to manage them (Head, 2011). Participation also contributes to redefining the role of social workers by permitting citizens to evaluate their own lives and the services they receive, thus changing the way such services are delivered.

From a formal standpoint, young people are a group which should be given special attention within the Pri- mary Social Care Services (SSAP) (Spanish Ministry of Labor and Social Affairs 2007). Indeed, social services legislation in Spain repeatedly underlines the importance of the principle of participation, including the planning, development, monitoring and evaluation of social services and social services professionals (Vilà, 2010). However, few studies specifically examine the views of young people compared to other service users, while research on quality standards in the social services are also lacking (Beresford 2007).

In 2007, the European Commission launched an initiative to develop a quality framework for social services that gives priority to participation by young people. The application of the framework within Europe, and in Spain in particular, has led to two important outcomes. The first is the growing number of initiatives to promote participation by young people at the European Union level, while the second is the rethinking of youth social services within the framework of Spanish legislation (Crespo and Moretón 2011).

From the legislative standpoint, youth social services have been designed based on the conception of young users as passive subjects. Youth are viewed as passive recipients of previously designed services rather than people involved in their own social care provision, even when they themselves request such services in a well thought out and conscious manner. This lack of mutual recognition has marked the relationship between Spanish youth (or the lack thereof) and social services. In order to reorient this interaction, three specific characteristics of Spanish youth must be taken into account.

First, Spanish youth are "digital natives". Young people in Spain interact intensively with the Internet and social networks (Table 2 ). In fact, many protest movements of an international scope such as the "indignados" movement were first organized through social networks in Madrid and then spread to other major cities around the world such as New York, London or Paris.

Table 2. Internet usage among youth aged 16-24 years old*

\begin{tabular}{|c|c|c|c|c|c|c|c|c|}
\hline & & 2007 & 2008 & 2009 & 2010 & 2011 & 2012 & 2013 \\
\hline & Users & $86,3 \%$ & $90,3 \%$ & $92,3 \%$ & $94,1 \%$ & $95,0 \%$ & $95,8 \%$ & $97,4 \%$ \\
\hline & Email & $87.4 \%$ & $88.8 \%$ & $92.3 \%$ & $90.5 \%$ & $92.6 \%$ & $90.2 \%$ & $91.2 \%$ \\
\hline 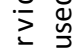 & Read newspapers and magazines & $38.0 \%$ & $39.4 \%$ & $46.2 \%$ & $54.4 \%$ & $61.0 \%$ & $59.3 \%$ & $66.6 \%$ \\
\hline$\stackrel{\sim}{\sim}$ & Social Networks (Facebook, Twitter, Tuenti...) & & & $58.7 \%$ & $67.6 \%$ & $88.5 \%$ & $92.2 \%$ & $94.5 \%$ \\
\hline
\end{tabular}

*Access to Internet services in the last three months.

Source: INE. 
Second, young people in Spain largely have a negative opinion of public social services for youth both in general terms (Figure 4) and in relation to specific measures such as the minimum emancipation income $^{6}$ (Figure 5).

Figure 4. Opinion of public social services for youth by age (\%) 2012

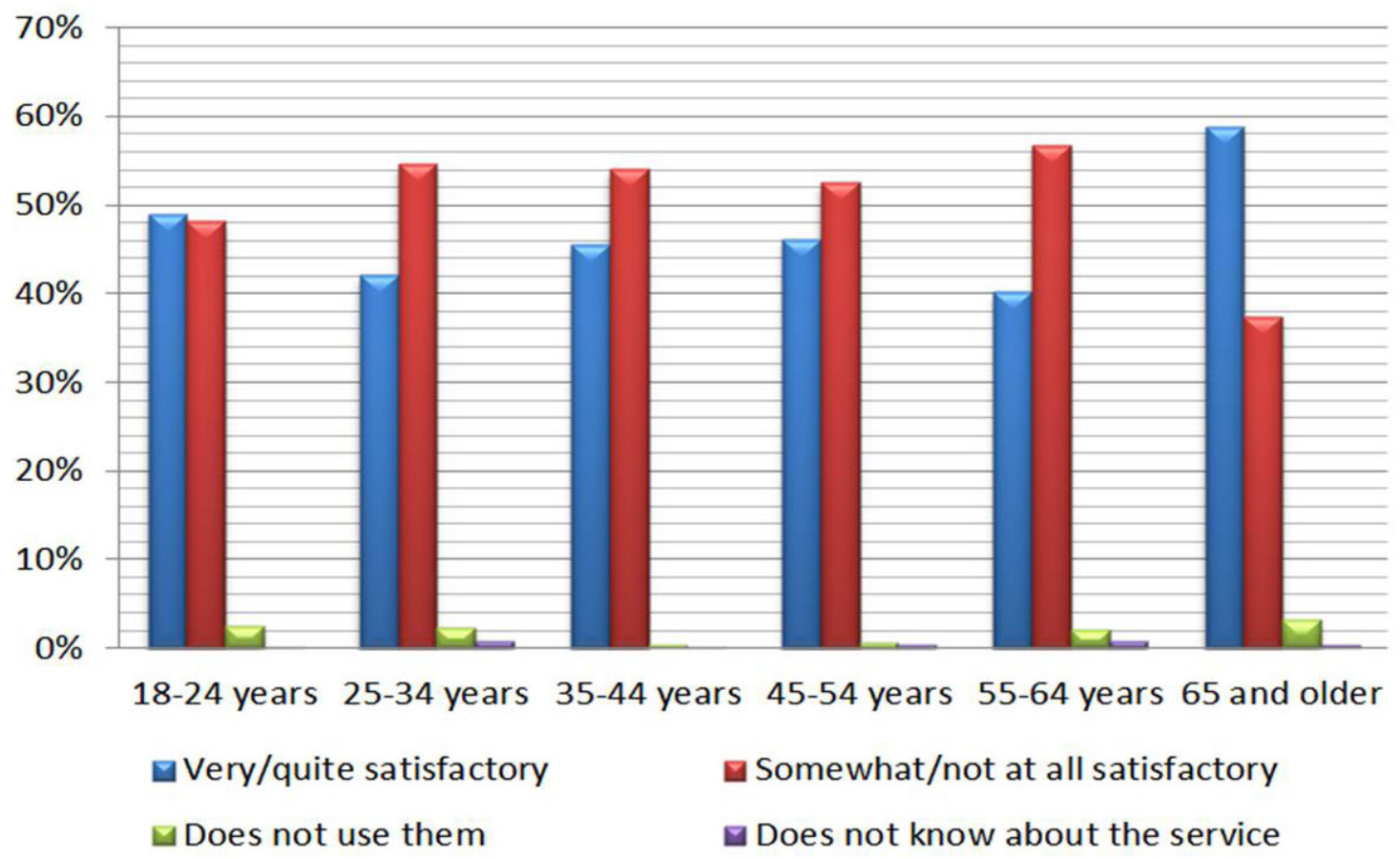

Source: The authors based on data from survey 2950 "Quality of Public Services" of the Spanish Center for Sociological Research (CIS) 2012.

Figure 5.Opinion of the management of minimum emancipation income policy by age (\%)

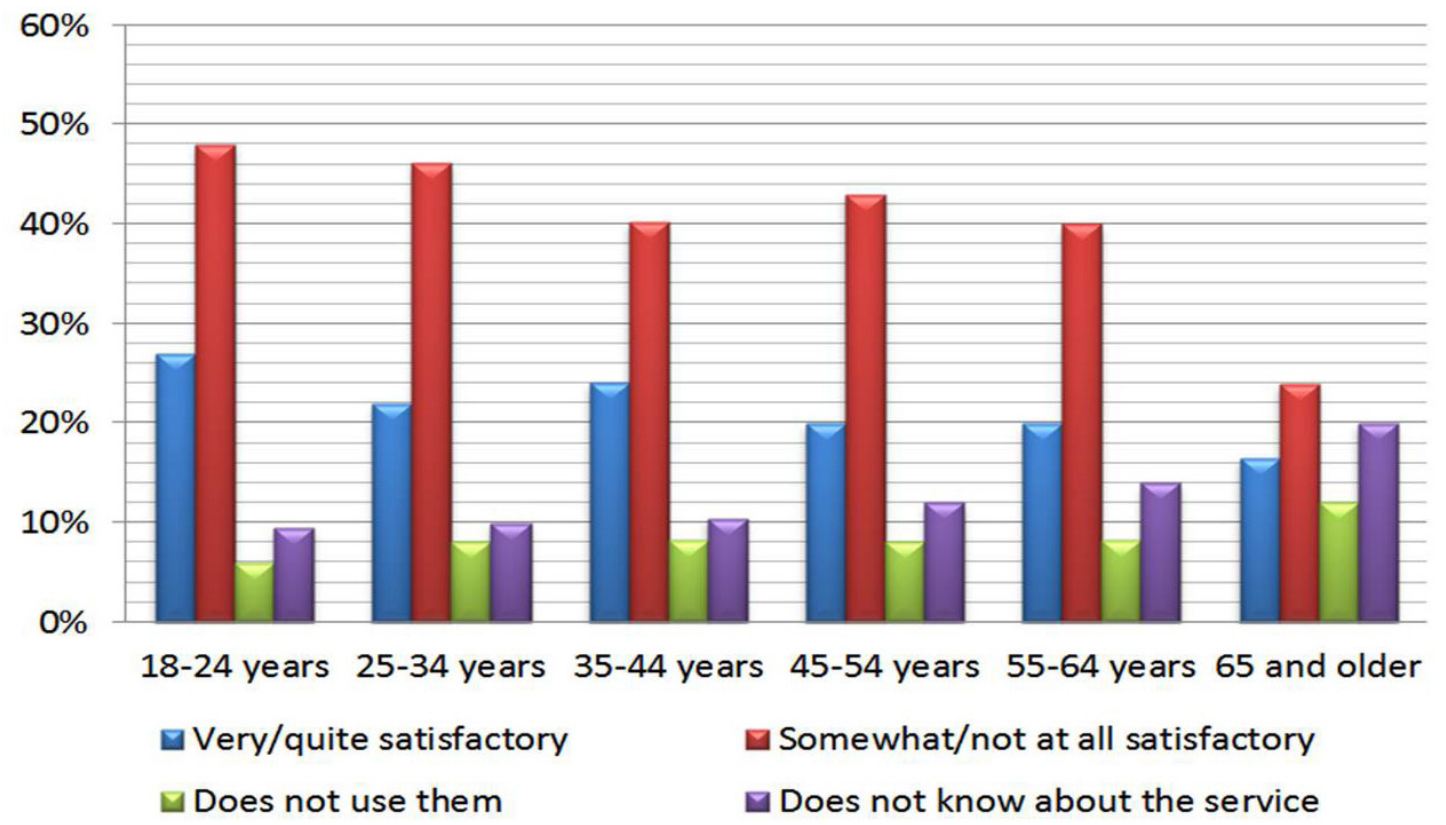

Source: The authors based on data from survey 2813 "Quality of Public Services" of the Spanish Center for Sociological Research (CIS) 2009. 
Third, the prevailing model of social integration within the social services focuses on employment and family dependence/independence (López Peláez, 2012). The consequence of this approach is that young users find themselves immersed in an adult world governed by its own relational rules and expectations. The social work professionals with whom young people interact apply an integration model designed to help them to cope with a wide variety of issues (i.e., substance abuse, family violence, school dropout, unemployment) rather than actively training the young and teaching them to adequately manage their identity and their present and future paths. Furthermore, given the challenges young people face in managing their educational, employment, residential and family transitions, the social services usually (except in cases of domestic violence) prefer that they remain in the family home; a protectionist mentality that comes into direct conflict with young users' desire for independence.

In short, social services are often characterized by a bureaucratic (focusing on the allocation of resources and benefits) and protectionist (seeking social benefits for each social problem that arises) approach to problems, in which young people experience real difficulties in recognizing themselves and being recognized as adults (Vidal 2009). Consequently, social workers in public institutions are often overwhelmed by a bureaucratic welfare model to which they must devote most of their time.

In recent years, this trend has been reflected at the legislative level, for example, by Law 16/2010 of December 20 concerning the Social Services of Castile and Leon, one of the seventeen autonomous communities that make up the Spanish state. This law redefines the social worker as a professional focused on "service delivery" whose main task is to manage a systematic and comprehensive catalog of previously established services, thereby reducing user "participation" to a merely rhetorical argument.

In the sphere of professional social work, and also in academia, this bureaucratic reorientation of the profession has been questioned on numerous occasions (De la Fuente Robles and Martín Cano 2012; Hopman, Winter and Koops, 2013). A large part of the working day of social workers is employed in delivering personalized care and managing benefits such as dependency aid or the minimum guaranteed income. These benefits are clearly of an assistentialist nature and are mostly assigned to older age groups. Given this situation, the Social Work Conferences (2004-2012) held in
Spain have recommend that focus be placed on social intervention practices that go beyond problem-centered counseling and the mere delivery of services.

In short, the bureaucratization of social work and the scant attention paid to "youth" in social service management systems have distanced social workers from citizens in general, and from young people in particular. In the social services field, the culture of participation (as citizens in an advanced democracy) has not materialized in the active participation by citizens in the design of social policies. In our opinion, it is precisely at this point where the gap, which is of a marked digital nature in the social services, is widest. Young digital natives cannot find a space for participation and service delivery in their natural environment, the network. Why does this occur? Because the social services in Spain operate in a non-digital world that is markedly assistentialist. Moreover, the specific problems facing youth are not assessed adequately and there are few programs and resources targeted specifically at them. As a result, young people do not feel that their needs are being met, lack avenues of participation in the design and implementation of youth policies and view social services activity in a negative manner.

\section{CONCLUSIONS}

As noted in the introduction, the autonomy, participation and independence of young people are one of the signs of identity of social policies in countries of northern Europe, and also play a key role in social policies of the European Union (Council of the European Union 2009). In relation to EU guidelines, and the practical experience of societies such as those of Finland or Sweden, the Spanish welfare system presents some specific and differentiating features: the delay in the age of emancipation, low participation by young people (except when mobilizing through social networks), lack of public policies for youth, reduced funding for these policies, and finally a progressive distancing between youth and social services. In this regard, it is important to analyze the theoretical model of integration of young people that derives from European legislation, as well as the practical reality of youth policies in countries of northern Europe, in relation to the Spanish case, specifically in terms of social services.

The detailed analysis of social service interventions with youth in Spain has led to four findings. First, Spanish youth are clearly in a situation of vulnerability due to the country's high youth unemployment rates. As a result, emancipation from the family of origin and 
incorporation into the labor market are, in many cases, impossible to achieve. In an aging society, youth social policies should be central in promoting empowerment and personal development (Morton and Montgomery, 2012) and ensuring generational reproduction. Yet the data for Spain show that the Spanish welfare state focuses precisely on other age groups. Second, youth are not a target group within the social services, despite the theoretical importance of youth policies. Young people are not assessed as such, and in the planning of social intervention activities youth are not taken into account. This is consistent with the Spanish welfare state system, which tends to reduce its performance for young people (in a context in which the family is the main provider of resources for young people). Third, because social services are designed for other age groups and other demands, young people are clearly dissatisfied with social policy and social services. Indeed, the system seems to have turned its back on youth who gradually distance themselves from the social services and public institutions. Fourth, Spanish youth interact intensively with new technologies and social networks, and use these channels to organize themselves and put their demands on the public agenda as the mass protests by Spanish youth on March 15, 2011 have shown. Given that the results of previous research studies show that youth welfare administrators can support service effectiveness with interventions that improve specific dimensions of culture and climate (Williams and Glisson, 2013). In order to foster participation by young people in the design of youth policies - an express objective of the European Union - the social services model must be redefined. Mechanisms must be developed to promote youth participation which take into account that young people are digital natives.

In this regard, further studies are needed to design strategies to enable the participation of young people online, reformulate Spanish social policies, and advance in the construction of a European citizenship for our youth. In our view, this should be a common goal for social services across Europe. In a context in which young Europeans are digital natives above all, old and new risks of social exclusion are redefined in the Internet, and new forms of participation must be developed through social networks as has been done in countries such as Finland (www.lastensuojelu.info). To address these new challenges, it is necessary to develop what we call online social work (Del Fresno 2011) to ensure that young people become a strategic sector both in Spain and other countries of the European Union.

\section{NOTES}

1 We refer to the specific job training of students in the school system that decide to direct their steps towards the working world as "vocational or initial". Job placement is the aim of this type of education.

$258.6 \%$ of all contracts awarded youth are temporary (Eurostat 2010).

3 The Information System of Social Services Users (SIUSS) is the source for Spanish data on general social services activity in fifteen autonomous communities and cities: Andalusia, Aragon, Asturias, Balearic Islands, Cantabria, Castile and Leon, Ceuta, Valencia, Extremadura,

\section{REFERENCES}

Aliena, R., Fombuena, J. and García Vilaplana, A. (2012). No es país para jóvenes. Los servicios sociales, la vida adulta y la exclusión social. Revista de Estudios de Juventud, 97, pp. 63-76.

Arias Astray, A. and Sánchez Moreno, E. (2012). El trabajo (social) con jóvenes y la problematización de la categoría ju-
Galicia, La Rioja, Madrid, Melilla, Murcia, and Navarra.

4 The social wage is a monthly payment made to individuals, families or cohabiting individuals that lack the resources to meet their basic needs. It guarantees individuals a minimum income in situations of severe poverty. Individuals can request the social wage without sacrificing other benefits they may receive (non-contributory pensions, unemployment benefits or other benefits and public pensions). The social wage supplements other income up to the established minimum income level.

ventud. Revista de Estudios de Juventud 97, pp. 77-92

Arias Astray, A. and Segado Sánchez-Cabezudo, S. (2013). El ámbito online en la metodología con grupos. En S. Segado Sánchez-Cabezudo, S. del Fresno García, M. y López Pelaéz, A. (eds). Modelos de Trabajo Social con Grupos. Madrid: Universitas, pp.107-128.
5 Emergency assistance is temporary financial aid intended to cover specific and basic expenses such as food, healthcare and clothing, or the maintenance of the habitual residence to prevent eviction or a utility shutoff, as well as for humanitarian reasons or other unforeseen events.

6 Economic assistance designed to promote the emancipation of young people by subsidizing part of rental housing costs. Adopted in 2007, this aid remained in force until 2012 when it was eliminated.

Beresford, P. (2007). The Changing Roles and Tasks of Social Work from Service Users' Perspectives: a literature informed discussion paper. London: Saphing Our Lives National User Network.

Börsch-Supan, A. (2007). European welfare state regimes and their generosity towards the elderly [on line] [Available 
from http://www.mea.mpisoc.mpg.de/ uploads/user_mea_discussionpapers/ nm3gpp87xjemjkx5_128-2007.pdf]

Bradley H. and van Hoof, J. (2005). Fractured transitions: the changing context of Young peoples'labour market situations in Europe. In Bradley, H. and van Hoof, J. (eds.). Young People in Europe. Bristol: The Policy Press, pp. 99-113.

Castells, M. and Himanen, P. (2002). The Information Society and the Welfare State: The Finnish Model. New York: Oxford University Press http://dx.doi.org/10.1093/acprof:o so/9780199256990.001.0001

Checkoway, B. and Aldana, A. (2013). Four forms of youth civic engagement for diverse democracy. Children and Youth Services Review, 35, pp. 1894-1899. http://dx.doi.org/10.1016/j.childyouth.2013.09.005

Chiuri M. C. and del Boca D. (2008). Household membership decision of adult children. IZA Discussion Paper 3546, pp. 1-29.

Coles B. (1995). Youth and Social Policy. London: Routledge.

Comas, D. (coord.). (2011). Las políticas públicas de juventud. Revista de Estudios de Juventud, 94.

Council of the European Union (2009). Youth Strategy (2010-2018). Luxembourg: Commission of the European Communities.

Crespo Garrido, M. and Moretón Sanz, F. (2011). Discriminación por razón de edad y sexo. Retos pendientes del Estado Social. Madrid: Colex.

Del Fresno García, M. (2011). Retos para la intervención social con las familias en el siglo XXI. Madrid: Trotta.

De la Fuente Robles, Y. and Martín Cano, C. (2012). Los servicios sociales y sus nuevas respuestas a la juventud. Revista de Estudios de Juventud, 97, pp. 109-122.

Domenech López, Y. and Giménez Bertomeu, V. M. (2012). Percepciones sobre la calidad de los servicios sociales de las personas jóvenes usuarias: utilidades para el diseño de estándares de calidad. Revista de Estudios de Juventud, 97, pp. 123-146.

Eurostat. (2009). European Union Labor Force Survey [on line]. Available from http://ec.europa.eu/eurostat/web/microdata/european-union-labour-forcesurvey
Eurostat. (2010). Combating poverty and social exclusion. A statisitical portrait of the European Union 2010. Luxemburgo: Publications Office of the European Union.

Featherstone, B., Broadhurst, K. and Holt, K. (2012). Thinking systemically-thinking politically: building strong partnerships with children and families in the context of rising inequality. Bristish Journal of Social Work, 42, 2, pp. 618-633. http:// dx.doi.org/10.1093/bjsw/bcr080

Finn, J., Nybell, L. M. and Shook, J. J. (2013). Place, power, and possibility: remaking social work with children and youth. Children and Youth Services Review, 35, pp. 1159-1165. http://dx.doi. org/10.1016/j.childyouth.2013.04.002

Freire Seoane, M. J. (2009). Los jóvenes y la flexibilidad laboral. Cuadernos de Economía, 32, 89, pp. 5-38.

Furlong, A. (2009). Handbook of youth and young adulthood: new perspectives and agendas. New York: Routledge.

García Montalvo, J. and Peiró, J. M. (2008). Análisis de la sobrecualificación y la flexibilidad laboral. Observatorio de Inserción Laboral de los Jóvenes 2008. Valencia: Instituto valenciano de investigaciones económicas, Fundación Bancaja.

Gorry, A. (2013). Minimum wages and youth unemployment. European Economic Review, 64, pp. 57-75. http://dx.doi. org/10.1016/j.euroecorev.2013.08.004

Greve, B. (2011). Welfare State and social policies in a time of economic crisis: the case of Denmark. Comunitania. Revista Internacional de Trabajo Social y Ciencias Sociales, 1, pp. 31-43. http://dx.doi. org/10.5944/comunitania.1.2

Head, B. W. (2011). Why not ask them? Mapping and promoting youth participation. Children and Youth Services review, 33, pp. 541-547. http://dx.doi. org/10.1016/j.childyouth.2010.05.015

Hopman, M., Winter, M. and Koops, W. (2013). The hidden curriculum of youth care interventions-A case study. Children and Youth Services Review, 35, pp. 237-243. http://dx.doi.org/10.1016/j. childyouth.2012.11.004

Instituto Nacional de Estadística (INE) (2013). Encuesta de Población Activa. Madrid: Instituto Nacional de Estadística. Available from http://www.ine.es/ inebaseDYN/epa30308/epa_inicio.htm

Kim, I., Muntaner, C., Shahidi, F., Vives, A., Vanroel, C. and Benach, J. (2012).
Welfare states, flexible employment, and health: A critical review. Health Policy, 104, 2, pp. 99-127. http://dx.doi. org/10.1016/j.healthpol.2011.11.002

Leccardi, C. and Ruspini, E. (2006). A new youth? New people, generations and family life. Aldershot: Ashgate.

López Peláez, A. (2012). Introducción: Jóvenes y Trabajo Social. Revista de Estudios de Juventud, 79, pp. 9-11.

López Peláez, A. and Segado Sánchez-Cabezudo, S. (2009a). Jóvenes, accidentes debidos al tráfico y riesgos laborales. Madrid: Instituto de la Juventud.

López Peláez, A. and Segado SánchezCabezudo, S. (2009b). Exclusión social, trabajo y salud: ¿puede un mercado de trabajo precario favorecer la inclusión social de los jóvenes? En Tezanos, J. F. (ed.) Juventud y Exclusión social. Décimo Foro sobre Tendencias Sociales. Madrid: Sistema, pp.165-188.

Moreno Mínguez, A. (2013). Economía, formación, empleo y consumo en tiempos de crisis. En: Moreno Mínguez, A. y Rodríguez San Julián, E.: Informe Juventud en España 2012. Madrid: INJUVE, pp. 79-164.

Moreno Mínguez, A., López Peláez, A. and Segado Sánchez-Cabezudo, S. (2012). La transición de los jóvenes a la vida adulta. Crisis económica y emancipación tardía. Barcelona: Obra Social la Caixa.

Morton, M. and Montgomery, P. (2012). Empowerment-based non-formal education for Arab youth: A pilot randomized trial. Children and Youth Services Review, 34, pp. 417-425. http://dx.doi. org/10.1016/j.childyouth.2011.11.013

Refrigeri, L. and Aleandri, G. (2013). Educational policies and youth unemployment. Procedia- Social and Behavioral Sciences, 92, pp. 1263-1268. http://dx.doi. org/10.1016/j.sbspro.2013.10.026

Teney, C. and Hanquinet, L. (2012). High political participation, high social capital? A relational analysis of youth social capital and political participation. Social Science Research, 41, 5, pp. 12131226. http://dx.doi.org/10.1016/j.ssresearch.2012.03.012

Tezanos, J. F. (2007). Juventud, ciudadanía y exclusión social. Sistema. Revista de Ciencias Sociales, 197-198, pp. 103-120.

Vidal Fernández, F. (2009). Pan y rosas. Fundamentos de exclusión social y políticas de empoderamiento. Madrid: Cáritas Española / Fundación Foessa. 
Vilà, A. (2010). Los cambios legislativos en materia de servicios sociales (20002009). En Casado, D. (coord.). Leyes de servicios sociales del siglo XXI. Madrid: Cáritas Española / Fundación Foessa, pp. 17-48.
Wallace, C. and Bendit, R. (2009). Youth policies in Europe: towards a classification of different tendencies in youth policies in the European Union. Perspectives on European Politics and Society, 10, 3, pp. 441-458. http://dx.doi. org/10.1080/15705850903105868
Williams, N. J. and Glisson, C. (2013). Testing a theory of organizational culture, climate and youth outcomes in child welfare systems: A United States national study. Child Abuse and Neglet. In press. www.dx.doi.org/10.1016/j. chiabu.2013.09.003 